1 Calnan M, Cant S, Gabe J. Going private. Why people pay for their health care. Buckingham: Open University Press, 1993

2 Saunders P, Harris C. Popular attitudes to social welfare services. London: Social Affairs University, 1989.

3 Taylor-Gooby P. Welfare attitudes: cleavage, consensus and citizenship. fournal of Social Affairs 1987;3:199-221.

4 Busfield J. Sectoral divisions in consumption: the case of medical care. Sociology 1990;24: $77-98$.
5 Scott EA, Black NA. Appropriateness of cholecystectomy: the public and private sectors compared. Ann R Coll Surg Eng 1992;74(suppl):97-101.

6 Black N, Petticrew M, McPherson K. Comparison of NHS and private patients undergoing elective transurethral resection of the prostate for benign prostatic hypertrophy. Quality in Health Care 1993;2:11-6.

7 Strong PM. The ceremonial order of the clinic. London: Routledge and Kegan Paul, 1979.

8 Silverman D. Going private: ceremonial forms in a private oncology clinic. Sociology 1984;18: $191-204$.

\title{
Whither health care in South Africa?
}

\section{Expanding primary health care is the only way forward}

Forty years of apartheid has allowed the development of sophisticated medical care for its supporters while the basic health needs of the disenfranchised majority have been deliberately neglected. As a result the health care services to the public sector in South Africa today are fragmented, underfunded, and both financially and geographically inaccessible to many communities, especially in periurban and rural areas.

In contrast, an expensive and overserviced private health care sector supplies a high level of care to one fifth of South Africans who form the elite, affluent sections of the community. Ironically, the provision of private health care is partially funded by the general public while medical schools train doctors suited best for private practice or export. Academic isolation has further damaged the standard of specialist care offered by the public service.

Recently, genuine efforts have been made by the government to rectify this. A very distorted public health service, however, will be inherited by a new, democratically elected government.

While these weaknesses bedevil the provision of health care for all, there remain well trained and highly motivated doctors and nurses and other health care workers in the country committed to a new era in health care. Seven medical schools, regional and district hospitals, and a good transport and communications infrastructure are already in place. What is awaited is an urgent restructuring of health care services. To plan and implement a health service that will address the deficiencies of the past presents an enormous challenge to both health care workers and the public.

What is needed is an effective and equitable health service. It would be based on an integrated, regionalised system that draws in all the current state, non-governmental, and private sectors. The most urgent need is for primary health care to be developed in all parts of the country. It should be linked to a comprehensive system of community health services and regional hospitals with an upward chain of referral and a downward chain of support. Given the limited resources available, the optimal use of staff and facilities is vital. Community clinics staffed by nurses are needed, with particular attention given to maternal and child health. To be acceptable to the community, primary care will have to be backed up by facilities for secondary care.

Many people view the availability of essential health care for all as a human right, which should be incorporated into a new constitution. A national health service, with a strong emphasis on primary care services aimed at redressing the inequalities of the past, is widely supported, and many progressive health planners favour adopting the World Health Organisation's concept of the district as the basic building block of such a service. Working models of such districts would need to be established to allow rational decisions to be made about the pattern of future services. Final details of funding and planning details will have to be reached by consensus as priorities and needs may vary widely between local communities.

Providing tertiary care is more problematical, given its expense and its need for many highly trained personnel. As a result, providing it to the standard demanded by the privileged minority in the past may not be possible. In the spirit of a free enterprise economy a parallel system of private health care should remain available for those who can afford it, but all public funding for private health care will have to be withdrawn.

Health and social and economic development are interdependent. Together with the development of a national health service, attention must be given to adequate housing, basic sanitation, an adequate supply of safe water, the promotion of public health, employment through sustained economic growth, improved nutrition, education, agricultural development, electrification, and respect for the environment.

The academic centres need to be reoriented to serve the needs of the whole population, entailing changes in service, teaching, and research. Medical schools and nursing colleges will have to equip their graduates with knowledge, attitudes, and skills needed for implementing a new health policy. The role of the nurse and possibly the traditional healer will expand, demanding many painful changes to current training programmes. Innovative educational methods will have to be devised to train the many health care workers who are presently providing services under difficult circumstances.

The limiting factors will be money and having too few health administrators who are capable of creating and maintaining a new system of health care. But the problems facing health care in South Africa are not insurmountable, and the country has the capacity to provide appropriate, acceptable, affordable, and equitable health care for all its people.

\section{DAVID WOODS} Associate professor DAVID POWER Professor

Department of Paediatrics and Child Health,

University of Cape Town,

Private Bag,

Rondebosch 7700

South Africa

\section{Correction}

\section{Gene therapy begins}

We regret that there were two errors in the editorial by Kay Davies and Bob Williamson (19 June, pp 1625-6). The first, for which the authors are responsible, is that most retroviral vectors are not derived from mouse mammary tumour virus (which has only rarely been suggested as a vector) but from another retrovirus, Moloney murine leukaemia virus. The second error was introduced during editing-the low density lipoprotein receptor controls the concentration of circulating cholesterol and not blood glucose. 